Цитирование: Ткаченко П.Е., Ивашкин В.Т., Маевская М.В. Клинические рекомендации по коррекции гепатотоксичности, индуцированной противоопухолевой терапией. Злокачественные опухоли : Практические рекомендации RUSSCO \#3s2, 2021 (том 11). 40

\title{
КЛИНИЧЕСКИЕ РЕКОМЕНААЦИИ ПО КОРРЕКЦИИ ГЕПАТОТОКСИЧНОСТИ, ИНДУЦИРОВАННОЙ ПРОТИВООПУХОЛЕВОЙ ТЕРАПИЕЙ
}

Коллектив авторов: Ткаченко П.Е., Ивашкин В.Т., Маевская М.В.

Ключевые слова: Гепатотоксичность, гипербилирубинемия, печёночная недостаточность, химиотерапия

\section{1. ОПРЕДЕЛЕНИЕ И ФАКТОРЫ РИСКА}

Гепатотоксичность - это повреждение печени, вызванное чужеродными веществами (ксенобиотиками). Частным случаем гепатотоксичности является лекарственное поражение печени (ЛПП) - повреждение, вызванное приёмом рецептурных либо безрецептурных лекарственных препаратов. Клинические проявления лПП могут быть представлены как острым, так и хроническим поражением печени, а по тяжести варьировать от бессимптомного повышения печёночных аминотрансфераз до развития фульминантной печёночной недостаточности. Отличительной особенностью подавляющего большинства препаратов, применяемых в химиотерапии онкологических заболеваний, является их исходная цитотоксичность. Это в значительной степени определяет гепатотоксический потенциал противоопухолевых препаратов, принимая во внимание центральную роль печени в их метаболизме. Патогенетические механизмы развития гепатотоксичности представлены на рис. 1.

\section{2. Факторы риска ЛпП}

\subsection{1. Определяемые организмом}

- Пожилой возраст

- Женский пол

- Беременность

- Генетическая предрасположенность

- Фоновые заболевания печени

- Особенности иммунного статуса

- Сопутствующие системные заболевания

- Количество принимаемых препаратов

- Пищевые факторы 


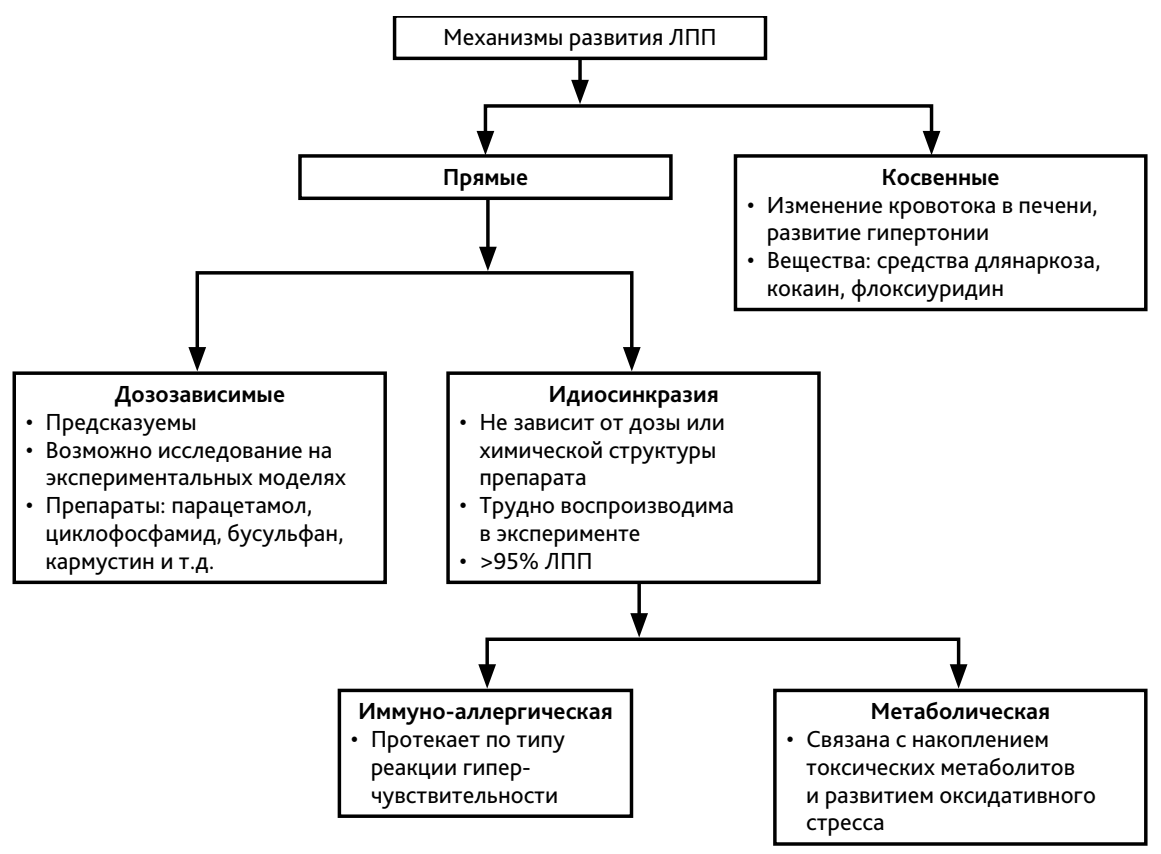

Рисунок 1. Лекарственное поражение печени.

\subsection{2. Определяемые препаратом}

- Суточная доза

- Метаболический профиль

- Риск взаимодействия с другими препаратами (особенно при полипрагмазии)

- Липосомальные препараты

\section{2. КЛАССИФИКАЦИЯ}

По клинико-морфологической картине выделяют следующие формы лПП:

- Гепатоцеллюлярные (цитолитические) поражения печени

- Холестатические поражения печени

- Смешанный тип поражения

- Сосудистые поражение печени

- Лекарственно индуцированный стеатоз/стеатогепатит

- Гранулематозный тип поражения 


\section{3. КЛИНИЧЕСКИЕ ПРОЯВЛЕНИЯ}

Гепатоцеллюлярная форма поражения печени характеризуется повышением АлТ более, чем в 2 раза относительно верхней границы нормы (ВГН). При этом также возможно повышение щелочной фосфатазы (ЩФ), являющейся маркёром холестаза. Для гепатоцеллюлярного поражения характерно соотношение АлТ/ЩФ $\geq 5$.

Холестатические поражения характеризуются канальцевым, паренхиматозно-канальцевым и внутрипротоковым холестазом. При этом отмечается повышение уровня ЩФ в 2 и более раз, соотношение Алт/ЩФ $\leq 2$.

При смешанной форме ЛПП как АЛТ, так и ЩФ повышены более, чем в два раза, причём соотношение АЛт/ЩФ находится в диапазоне от 2 до 5 (табл. 1).

Таблица 1. Варианты паренхиматозного поражения печени

\begin{tabular}{|l|l|}
\hline Тип повреждения & Биохимические показатели \\
\hline Гепатоцеллюлярный & АЛТ $>2 \mathrm{~N}$ или соотношение АЛТ/ЩФ $\geq 5$ \\
\hline Холестатический & ЩФ >2N или соотношение АЛТ/ЩФ $\leq 2$ \\
\hline Смешанный & АЛТ $>2 \mathrm{~N}$ и ЩФ $>2 \mathrm{~N} ;$ соотношение АЛТ/ЩФ от 2-5 \\
\hline
\end{tabular}

Лекарственные взаимодействия - частая причина развития нежелательных явлений и гепатотоксичности. Пациенты с онкологическими заболеваниями помимо противоопухолевой терапии получают ряд лекарственных препаратов, направленных на коррекцию осложнений химиотерапии и лечение сопутствущих заболеваний (обезболивающие, противорвотные, противосудорожные и т. д.), что повышает риск лекарственных взаимодействий.

Наиболее важен фармакокинетический тип взаимодействия - когда один препарат влияет на абсорбцию, распределение, метаболизм или экскрецию другого препарата. Поскольку большинство лекарственных препаратов метаболизируются при участии системы цитохромов P450, а определённые лекарственные вещества могут быть индукторами или ингибиторы цитохромов данной системы, риск развития нежелательных явлений возрастает.

В табл. 2 приведены индукторы и блокаторы изоферментов CYP450, а также субстраты из числа основных противоопухолевых препаратов. Кроме того, для оценки потенциального взаимодействия лекарственных препаратов, могут быть использованы электронные ресурсы.

Таблица 2. Основные блокаторы и индукторы изоферментов СYР450

\begin{tabular}{|c|c|c|}
\hline Субстраты & Ингибиторы & Индукторы \\
\hline \multicolumn{3}{|l|}{ CYP1A2 } \\
\hline 5-фторурацил & Амиодарон & Рифампицин \\
\hline Дакарбазин & Амитриптилин & Пантопразол \\
\hline \multirow[t]{2}{*}{ Оксалиплатин } & Амлодипин & \\
\hline & Ибесартан & \\
\hline
\end{tabular}




\begin{tabular}{|c|c|c|}
\hline Субстраты & Ингибиторы & Индукторы \\
\hline & Карбамазепин & \\
\hline & Кларитромицин & \\
\hline & Кломифен & \\
\hline & Котримоксазол & \\
\hline & Омепразол & \\
\hline & Ондасетрон & \\
\hline & Флувастатин & \\
\hline & Ципрофлоксацин & \\
\hline \multicolumn{3}{|l|}{ CYP2B6 } \\
\hline Ифосфамид & Амлодипин & Верапамил \\
\hline \multirow[t]{12}{*}{ Циклофосфамид (индуктор) } & Доксорубицин & Аторвастатин \\
\hline & Итраконазол & Флувастатин \\
\hline & Кетоконазол & Нифедипин \\
\hline & Клопидогрел & Метамизол \\
\hline & Клотримоксазол & Клофибрат \\
\hline & Пароксетин & Дексаметазон \\
\hline & Сертралин & Нилотиниб \\
\hline & Сорафениб & Фенобарбитал \\
\hline & Тамоксифен & Фенитоин \\
\hline & Тиклопедин & Рифампицин \\
\hline & Цисплатин & Сульфинпиразон \\
\hline & & Карбамазепин \\
\hline \multicolumn{3}{|l|}{ CYP3A } \\
\hline Цитарабин & Циметидин & Карбамазепин \\
\hline Бусульфан & Кларитромицин & Эфавиренц \\
\hline Ифосфамид & Дилтиазем & Фенобарбитал \\
\hline Доксорубицин (ингибитор) & Эритромицин & Фенитоин \\
\hline Паклитаксел & Флуконазол & Пиоглитазон \\
\hline Доцетаксел & Кетоконазол & Рифампицин \\
\hline Винкристин & Ритонавир & \\
\hline Топотекан (ингибитор) & Верапамил & \\
\hline \multicolumn{3}{|l|}{ Иринотекан } \\
\hline \multicolumn{3}{|l|}{ Этопозид } \\
\hline \multicolumn{3}{|l|}{ Эрлотиниб } \\
\hline Гефитиниб & & \\
\hline
\end{tabular}




\begin{tabular}{|c|c|c|}
\hline Субстраты & Ингибиторы & Индукторы \\
\hline \multicolumn{3}{|l|}{ Сорафениб } \\
\hline \multicolumn{3}{|l|}{ Пазопаниб } \\
\hline \multicolumn{3}{|l|}{ CYP2C9 } \\
\hline Капецитабин (ингибитор) & Амиодарон & Рифампицин \\
\hline \multirow[t]{21}{*}{ Цисплатин (ингибитор) } & Амлодипин & Карбамазепин \\
\hline & Аторвастатин & Циклофосфамид \\
\hline & Варфарин & Дексаметазон \\
\hline & Валсартан & Фенобарбитал \\
\hline & Диазепам & \\
\hline & Диклофенак & \\
\hline & Ибупрофен & \\
\hline & Изониазид & \\
\hline & Кетоконазол & \\
\hline & Лансопразол & \\
\hline & Метронидалоз & \\
\hline & Нифедипин & \\
\hline & Омепразол & \\
\hline & Пантопразол & \\
\hline & Розувастатин & \\
\hline & Тамоксифен & \\
\hline & Тиклопидин & \\
\hline & Триметоприм & \\
\hline & Флувастатин & \\
\hline & Флуконазол & \\
\hline & Циклоспорин & \\
\hline \multicolumn{3}{|l|}{ CYP2E1 } \\
\hline Дакарбазин & Амитриптелин & Клофибрат \\
\hline \multirow[t]{8}{*}{ Оксалиплатин } & Хлорпромазин & Колхицин \\
\hline & Циметидин & Фенобарбитал \\
\hline & Кломифен & Рифампицин \\
\hline & Клоназепам & \\
\hline & Клотримоксазол & \\
\hline & Диазепам & \\
\hline & Диклофенак & \\
\hline & Этанол & \\
\hline
\end{tabular}




\begin{tabular}{|l|l|l|}
\hline Субстраты & Ингибиторы & Индукторы \\
\hline & Эторикоксиб & \\
\hline & Изониазид & \\
\hline & Итраконазол & \\
\hline & Мидазолам & \\
\hline & Никотинамид & \\
\hline & Нифедипин & \\
\hline & Пропофол & \\
\hline & Силденафил & \\
\hline & Тиклопидин & \\
\hline & Удхк & \\
\hline
\end{tabular}

Спектр клинических проявлений ЛПП варьирует от бессимптомного повышения печёночных аминотрансфераз до развития желтухи, холестаза, обструкции синусоидов, прогрессирования фиброза и развития фулминантной печёночной недостаточности. Тщательный анализ всех факторов риска, контроль сопутствующих заболеваний, подбор оптимальной терапии позволяет снизить вероятность возникновения лПП. Однако в большинстве случаев повреждение печени протекает по механизму идиосинкразии, что в значительной степени затрудняет оценку риска его развития.

При сосудистых поражениях в патологический процесс могут вовлекаться ветви воротной вены, печёночной артерии, печёночной вены, центральных вен и синусоидов. Механизм их развития до конца не известен. При синдроме обструкции синусоидов (СОС) отмечается повреждение эндотелиальных клеток, что, в свою очередь, приводит кистончению интимы и выходу эритроцитов в пространство Диссе. Агрегация эндотелиальных клеток и эритроцитов в синусоидах создаёт препятствие венозному оттоку, приводя к стазу крови и расширению синусоидов. Развивается фиброз и облитерация центральных вен, что может приводить к центрилобулярному некрозу гепатоцитов. Клинические проявления СОС характеризуются быстрым увеличением размеров и повышением плотности печени, нарастанием асцита. В биохимическом анализе крови преобладает повышение маркёров холестаза (ЩФ, ГГТ). СОС наиболее часто наблюдается у пациентов на этапе подготовки к трансплантации костного мозга. Факторами риска выступают высокие дозы облучения, а также бусульфан, цитарабин, циклофосфамид, кармустин, митомицин, 6-меркаптопурин, азатиоприн, дакарбазин и оксалиплатин.

Лекарственно-индуцированный стеатоз морфологически может быть представлен как крупнокапельной, так и мелкокапельной жировой инфильтрацией гепатоцитов. Поражение развивается в результате нарушения окислительного фосфорилирования в митохондриях. Клинически стеатоз протекает бессимптомно и может быть выявлен с помощью лучевых методов диагностики. Присоединение воспалительной реакции ведёт к лекарственноиндуцированному стеатогепатиту; он характеризуется повышением уровня печёночных аминотрансфераз и может приводить к развитию фиброза и цирроза печени. 
Важным аспектом снижения риска развития ЛПП является обследование пациента с целью исключения существующей патологии печени до назначения противоопухолевой химиотерапии. При выявлении фонового заболевания печени необходимо определить его значение для жизненного прогноза больного, возможность проведения противоопухолевой химиотерапии. Нарушение функции печени влияет на фармакокинетику и фармакодинамику многих химиопрепаратов. Уменьшение печёночного кровотока и общего количества функционирующих гепатоцитов снижает клиренс препарата, а низкий уровень альбумина изменяет объём распределения лекарственного вещества.

\section{4. ДИАГНОСТИКА}

1. Сбор жалоб и анамнеза

2. Врачебный осмотр

3. Лабораторная диагностика (клинический и биохимический (+альбумин, электролиты) анализы крови, АФП, коагулограмма (МНО, ПИ), общий анализ мочи

4. Диагностика вирусных гепатитов

a. Определение поверхностного антигена к гепатиту В (HBsAg)

b. Если $\mathrm{HBSAg}+$ : HBeAg, HBeAb и количественное определение ДНК HBV, HDVAb

c. Определение антител к ядерному антигену гепатита В (HBc Ab) IgG

d. Определение антител к гепатиту C (HCV), если позитивные: определение количества РНК в плазме, определение генотипа и консультация гепатолога

5. Оценка функционального статуса печени по классификации Child-Pugh (CP) для случаев известного фонового цирроза печени. Каждый признак в зависимости от выраженности оценивается в баллах от 1 до 3 (табл. 3). Сумма баллов 5-6, 7-9 и 10-15 классифицируются как СР класса А, В и С соответственно

6. УзИ органов брюшной полости и забрюшинного пространства.

Таблица 3. Балльная система Child-Pugh при циррозе печени

\begin{tabular}{|l|l|l|l|}
\hline Характеристика & $\mathbf{1 6 а л л ~}$ & 2 балла & 3 балла \\
\hline $\begin{array}{l}\text { Энцефалопатия } \\
\text { (степень) }\end{array}$ & Нет & $\begin{array}{l}\text { I-ІІ степень (или } \\
\text { компенсируется } \\
\text { меди- каментозно) }\end{array}$ & $\begin{array}{l}\text { III-IV степень (или } \\
\text { рефрактерная) }\end{array}$ \\
\hline Асцит & Нет & «Незначительный» & «Умеренный» \\
\hline Альбумин плазмы (г/дл) & $>3,5$ & $2,8-3,5$ & $<2,8$ \\
\hline $\begin{array}{l}\text { Протромбиновое время, } \\
\text { увеличение, сек. } \\
\text { (N=12-14 сек.) }\end{array}$ & $+1-4$ сек & $+4-6$ сек & $>+6$ сек. \\
\hline или МНО & $<1,7$ & $1,7-2,3$ & $>2-3$ мг/дл (или \\
\hline Общий билирубин & $\begin{array}{l}\text { (-2 мг/дл } \\
\text { (или<34,2 мкмоль/л) }\end{array}$ & $\begin{array}{l}>3 \text { мг/дл } \\
\text { (или }>51,3 \text { мкмоль/л) }\end{array}$ \\
\hline
\end{tabular}


Для диагностики ЛПП у больных с фоновой патологией печени с момента назначения противоопухолевой химиотерапии необходимо проведение мониторинга биохимических показателей крови (общий билирубин, альбумин, АЛТ, АСТ, ЩФ) 1 раз в 7-14 дней. Для уточнения диагноза могут использоваться лучевые методы диагностики (например, для выявления сосудистого поражения, развития билиарной патологии). При необходимости возможна пункционная биопсия и морфологическое исследование паренхимы печени.

Необходим тщательный анализ принимаемых пациентом препаратов с учётом дозировки и длительности приёма. Изменения биохимических показателей вскоре после назначения препарата и последующая нормализация после его отмены свидетельствуют в пользу лекарственной гепатотоксичности. Тем не менее, в большинстве случаев диагностика лПП бывает затруднительной, особенно у пациентов с уже имеющимся заболеванием печени, а также у больных, получающих одновременно несколько препаратов. Помимо этого необходимо оценивать роль опухолевого поражения печени, а также возможное развитие паранеопластического синдрома. Для оценки вероятности ЛПП может применяться шкала CIOMS/RUCAM (Councils for International Organizations of Medical Sciences/Roussel Uclaf Causality Assessment Method), оценивающая факторы риска, токсический потенциал препарата, наличие сопутствущей терапии и течение заболевания, а также временную связь между приёмом препарата с развитием клинических проявлений (http:/ / www.pmidcalc.org/?sid =8 229 110\&newtest =Y).

Для оценки тяжести гепатотоксичности также используются критерии Национального института изучения рака (National Cancer Institute, NCI), (табл. 4). Изолированное повышение печёночных ферментов не всегда свидетельствует о развитии органной недостаточности, в связи с чем необходимо проведение всесторонней оценки показателей.

Таблица 4. Критерии тяжести гепатотоксичности Национального института рака США

\begin{tabular}{|l|l|l|l|l|}
\hline \multirow{2}{*}{ Параметр } & \multicolumn{4}{l|}{ Степень гепатотоксичности } \\
\cline { 2 - 5 } & I & II & III & IV \\
\hline $\begin{array}{l}\text { Щелочная } \\
\text { фосфатаза (ЩФ) }\end{array}$ & $<2,5$ ВГН & $2,5-5$ ВГН & $>5-20$ ВГН & $>20$ ВГН \\
\hline Общий билирубин & $<1,5$ ВГН & $1,5-3$ ВГН & $3-10$ ВГН & $>10$ ВГН \\
\hline $\begin{array}{l}\text { Гамма-глутамил- } \\
\text { транс-пептидаза (ГГТ) }\end{array}$ & $<2,5$ ВГН & $2,5-5$ ВГН & $5-20$ ВГН & $>20$ ВГН \\
\hline АСТ & $<2,5$ ВГН & $2,5-5$ ВГН & 5-20 ВГН & $>20$ ВГН \\
\hline АЛТ & $<2,5$ ВГН & $2,5-5$ ВГН & 5-20 ВГН & $>20$ ВГН \\
\hline $\begin{array}{l}\text { Печёночная } \\
\text { недостаточность }\end{array}$ & Нет & Нет & $\begin{array}{l}\text { Астериксис } \\
\text { порхающий } \\
\text { тремор) }\end{array}$ & $\begin{array}{l}\text { Тяжёлая энцефалопатия, } \\
\text { кома }\end{array}$ \\
\hline Портальный кровоток & Норма & Снижен & $\begin{array}{l}\text { Ретроградный } \\
\text { кровоток, } \\
\text { ВРВП/асцит }\end{array}$ & $\begin{array}{l}\text { Состояние, требующее } \\
\text { экстренного оперативного } \\
\text { вмешательства }\end{array}$ \\
\hline
\end{tabular}

ВГН-верхняя граница нормы, ВРВП-варикозное расширение вен пищевода/желудка 
Для оценки тяжести ЛПП и прогноза заболевания также могут использоваться критерии тяжести гепатотоксичности группы по изучению лекарственно-индуцированных поражений печени Национального института здоровья (NIH DILI network), основанные на анализе показателей АЛТ, ЩФ, общего билирубина и МНО.

В табл. 5 представлены наиболее распространённые варианты лПП, наблюдаемые при проведении противоопухолевой химиотерапии.

Таблица 5. Частота развития ЛПП на фоне использования основных химиопрепаратов

\begin{tabular}{|c|c|c|}
\hline Класс препаратов & Препарат & Частота развития гепатотоксичности \\
\hline \multirow[t]{5}{*}{ Антиметаболиты } & 5-фторурацил & Повышение АСТ/АЛТ в 70\% случаев \\
\hline & Капецитабин & $\begin{array}{l}\text { АСТ/АЛТ > } 5 \text { ВГН в <1\% случаев } \\
\text { Умеренное повышение билирубина }>40 \%\end{array}$ \\
\hline & Гемцитабин & $\begin{array}{l}\text { Повышение АСТ/АЛТ в 30-70\% случаев АЛТ > } 5 \text { ВГН } \\
\text { в 5-12\% случаев } \\
\text { Повышение билирубина, ЩФ - редко }\end{array}$ \\
\hline & Метотрексат & Повышение АСТ/АЛТ в 15-50\% случаев \\
\hline & Пеметрексед & $\begin{array}{l}\text { Повышение АСТ/АЛТ в 30-60\% случаев Повышение } \\
\text { билирубина, ЩФ - редко }\end{array}$ \\
\hline \multirow[t]{6}{*}{ Алкилирующие агенты } & Циклофосфамид & Повышение АСТ/АЛТ в 70\% случаев \\
\hline & Ифосфамид & Умеренное повышение АСТ/АЛТ \\
\hline & Оксалиплатин & Умеренное повышение АСТ/АЛТ \\
\hline & Цисплатин & Небольшое повышение АСТ/АЛТ \\
\hline & Карбоплатин & Повышение АСТ/АЛТ в 30\% случаев \\
\hline & Дакарбазин & Умеренное повышение АСТ/АЛТ \\
\hline \multirow[t]{2}{*}{$\begin{array}{l}\text { Противоопухолевые } \\
\text { антибиотики }\end{array}$} & $\begin{array}{l}\text { Доксорубицин } \\
\text { и эпирубицин }\end{array}$ & Повышение АСТ/АЛТ в 40\% случаев \\
\hline & Блеомицин & Повышение АСТ/АЛТ от $10 \%$ до 30\% случаев \\
\hline \multirow{4}{*}{$\begin{array}{l}\text { Препараты, воздей- } \\
\text { ствующие на тубулин }\end{array}$} & Винкаалкалоиды & Повышение АСТ/АЛТ от 5\% до 10\% случаев \\
\hline & Трабектедин & Повышение АСТ/АЛТ в 40\% случаев \\
\hline & Паклитаксел & Повышение АСТ/АЛТ от $7 \%$ до 26\% случаев \\
\hline & Доцетаксел & Умеренное повышение АСТ/АЛТ \\
\hline \multirow[t]{3}{*}{$\begin{array}{l}\text { Ингибиторы топо- } \\
\text { изомеразы }\end{array}$} & Иринотекан & $\begin{array}{l}\text { Повышение АСТ/АЛТ > } 15 \% \text { случаев в комбинации } \\
\text { с другими препаратами } \\
\text { Выраженное повышение АСТ/АЛТ от } 1 \% \text { до } 4 \% \\
\text { случаев }\end{array}$ \\
\hline & Топотекан & $\begin{array}{l}\text { Повышение АСТ/АЛТ > 15\% случаев } \\
\text { Выраженное повышение АСТ/АЛТ от 1\% до 4\% } \\
\text { случаев }\end{array}$ \\
\hline & Этопозид & $\begin{array}{l}\text { Повышение АСТ/АЛТ от 5\% до 100\% случаев } \\
\text { в комбинации с другими препаратами }\end{array}$ \\
\hline
\end{tabular}




\begin{tabular}{|c|c|c|}
\hline Класс препаратов & Препарат & Частота развития гепатотоксичности \\
\hline \multirow[t]{2}{*}{$\begin{array}{l}\text { Моноклональные } \\
\text { антитела }\end{array}$} & $\begin{array}{l}\text { Ипилимумаб, } \\
\text { ниволумаб, } \\
\text { пембролизумаб }\end{array}$ & $\begin{array}{l}\text { Описаны отдельные случаи развития ЛПП I-IV степени } \\
\text { тяжести, вплоть до фульминантной печёночной } \\
\text { недостаточности }\end{array}$ \\
\hline & Бевацизумаб & Возможность протективного эффекта \\
\hline \multirow[t]{8}{*}{$\begin{array}{l}\text { (Мульти) киназные } \\
\text { ингибиторы }\end{array}$} & Эрлотиниб & $\begin{array}{l}\text { Умеренное повышение АСТ/АЛТ } \\
\text { Повышение АСТ/АЛТ > } 5 \text { ВГН в > } 10 \% \text { случаев }\end{array}$ \\
\hline & Гефитиниб & $\begin{array}{l}\text { Повышение АСТ/АЛТ от } 9 \text { до 13\% случаев } \\
\text { Повышение АСТ/АЛТ > } 5 \text { ВГН в 2-4\% случаев }\end{array}$ \\
\hline & Лапатиниб & $\begin{array}{l}\text { Повышение АСТ/АЛТ от } 5 \% \text { до } 15 \% \text { случаев } \\
\text { Повышение АСТ/АЛТ > } 5 \text { раз - редко }\end{array}$ \\
\hline & Сорафениб & $\begin{array}{l}\text { Умеренное повышение АСТ/АЛТ } \\
\text { Повышение АСТ/АЛТ > } 5 \text { ВГН 1-3\% случаев }\end{array}$ \\
\hline & Пазопаниб & $\begin{array}{l}\text { Повышение АСТ/АЛТ в > 50\% случаев } \\
\text { Повышение АСТ/АЛТ > } 5 \text { ВГН в > } 8 \% \text { случаев } \\
\text { Увеличение уровня общего билирубина в } 30 \% \text { случаев } \\
\text { Комбинация увеличения уровня общего билирубина } \\
\text { и АЛТ в 1-2\% случаев }\end{array}$ \\
\hline & Сунитиниб & $\begin{array}{l}\text { Повышение АСТ/АЛТ в > 40\% случаев } \\
\text { Повышение АСТ/АЛТ > } 5 \text { ВГН в > 2-3\% случаев } \\
\text { Редко - гипераммониемия и развитие печёночной } \\
\text { энцефалопатии }\end{array}$ \\
\hline & Регорафениб & $\begin{array}{l}\text { Повышение АСТ/АЛТ в 39-45\% случаев } \\
\text { Повышение АСТ/АЛТ > } 5 \text { ВГН в 3-6\% случаев } \\
\text { Редко - гипераммониемия и развитие печёночной } \\
\text { энцефалопатии }\end{array}$ \\
\hline & Вемурафениб & $\begin{array}{l}\text { Повышение АСТ/АЛТ в } 30 \% \text { случаев } \\
\text { Повышение АСТ/АЛТ > } 5 \text { ВГН в 3\% случаев }\end{array}$ \\
\hline \multirow[t]{2}{*}{$\begin{array}{l}\text { Гормональные } \\
\text { препараты }\end{array}$} & Тамоксифен & $\begin{array}{l}\text { Развитие неалкогольной жировой болезни печени } \\
\text { в } 40 \% \text { случаев к } 1 \text { году применения }\end{array}$ \\
\hline & Абиратерон & $\begin{array}{l}\text { Описаны отдельные случаи развития ЛПП I-IV степени } \\
\text { тяжести }\end{array}$ \\
\hline
\end{tabular}

ВГН-верхняя граница нормы

\section{5. ЛЕЧЕНИЕ}

Лечение проводится в соответствии с действующими национальными рекомендациями и должна учитывать онкологический статус пациента. Может потребоваться коррекция дозы противоопухолевого химиопрепарата с низким терапевтическим индексом и/или если препарат метаболизируется при участии СРРЗА4/5, активность которого снижается при хронических заболеваниях печени.

Наиболее сложной проблемой является возможность противоопухолевого лечения при нарушении белково-синтетической (уровень $\mathrm{MHO}>1,2$, альбумин <30г/л, неопухолевый рефрактерный асцит) и детоксикационной (общий билирубин >51,3 мкмоль/л) функций 
печени. При наличии исходной печёночной недостаточности назначение определённых химиотерапевтических агентов может потребовать коррекцию их дозы (примеры коррекции дозы препаратов представлены в табл. 7).

\section{1. Лечение гепатотоксичности у пациентов, получающих противоопухолевую терапию}

Поскольку гепатотоксичность на фоне противоопухолевой терапии чаще всего обусловлена идиосинкразией, возможности лекарственной коррекции и/или лечения ЛПП весьма ограниченны. В большинстве клинических ситуаций коррекция и лечение лекарственноиндуцированной гепатотоксичности невозможны без редукции доз противоопухолевых химиопрепаратов. Для большинства химиотерапевтических схем выработаны конкретные рекомендации по изменению дозировки, основываясь на степени тяжести лекарственного поражения печени (табл. 7). Общие рекомендации по ведению пациентов с развитием лекарственно-индуцированного поражения печени на фоне проводимой химиотерапии базируются на критериях тяжести гепатотоксичности Национального института рака США (табл. 4). При изменении биохимических показателей, соответствующих 1 степени гепатотоксичности, возможно продолжить проведение химиотерапии с тщательным мониторингом лабораторных показателей пациента (оценка биохимических показателей, функциональных печёночных тестов) 1-2 раза в неделю. У больных с лекарственным поражением печени 2 степени необходимо рассмотреть возможность уменьшения дозы или временного прекращения приёма химипрепарата. Также требуется проведение оценки динамики биохимических показателей крови с частотой 1 раз в 3-4 дня. Развитие гепатотоксичности 3-4 степени диктует необходимость временной или полной отмены химиопрепарата, проведение оценки биохимических показателей крови 1 раз в 2 дня для обеспечения своевременной диагностики развития фульминантной печёночной недостаточности.

Таблица 7. Коррекция доз противоопухолевых химиопрепаратов

\begin{tabular}{|c|c|c|c|c|}
\hline Препарат & $\begin{array}{l}\text { Общий } \\
\text { билирубин, мг/дл }\end{array}$ & $\begin{array}{l}\text { Амино- } \\
\text { трансферазы }\end{array}$ & $\begin{array}{l}\text { Щелочная } \\
\text { фосфатаза }\end{array}$ & $\begin{array}{l}\text { Снижение дозы от исходной } \\
\text { (\%) }\end{array}$ \\
\hline Цитарабин & - & Любые & - & 50 \\
\hline \multirow[t]{2}{*}{ Циклофосфамид } & $3,1-5,0$ & $>3$ ВГН & - & 75 \\
\hline & $>5,0$ & & & 0 \\
\hline Дактиномицин & - & Любые & - & 50 \\
\hline \multirow[t]{4}{*}{ Доксорубицин } & & $>3 \mathrm{~B} Г \mathrm{H}$ & - & 75 \\
\hline & $1,2-3,0$ & $>3$ ВГН & & 50 \\
\hline & $3-5,0$ & & & 25 \\
\hline & $>5,0$ & & & 0 \\
\hline \multirow[t]{3}{*}{ Даунорубицин } & $1,2-3,0$ & - & - & 75 \\
\hline & $3-5,0$ & & & 50 \\
\hline & $>5,0$ & & & 0 \\
\hline
\end{tabular}




\begin{tabular}{|c|c|c|c|c|}
\hline Препарат & $\begin{array}{l}\text { Общий } \\
\text { билирубин, мг/дл }\end{array}$ & $\begin{array}{l}\text { Амино- } \\
\text { трансферазы }\end{array}$ & $\begin{array}{l}\text { Щелочная } \\
\text { фосфатаза }\end{array}$ & $\begin{array}{l}\text { Снижение дозы от исходной } \\
\text { (\%) }\end{array}$ \\
\hline 5-фторурацил & $>5,0$ & - & - & 0 \\
\hline Этопозид & $1,5-3,0$ & $\mathrm{ACT}>3 \times \mathrm{B} \Gamma \mathrm{H}$ & - & 50 \\
\hline Гемцитабин & $>1,6$ & - & - & Начинать с 800 мг $/ \mathrm{M}^{2}$ \\
\hline Ифосфамид & $>3,0$ & - & - & 25 \\
\hline Иринотекан & $1,5-3,0$ & - & - & 75 \\
\hline \multirow[t]{2}{*}{ Метотрексат } & $3,1-5,0$ & $>3$ ВГН & - & 75 \\
\hline & $>5,0$ & & & 0 \\
\hline \multirow[t]{3}{*}{ Паклитаксел } & $<1,5$ & В 2 раза >BГН & - & 75 \\
\hline & $1,6-3,0$ & & & 40 \\
\hline & $>3,0$ & & & 25 \\
\hline \multirow[t]{3}{*}{ Доцетаксел } & - & $>$ >1,5 ВГН & - & 100 \\
\hline & & 1,6-6 ВГН & & 75 \\
\hline & & $>6 \mathrm{~B} \Gamma \mathrm{H}$ & & На усмотрение лечащего врача \\
\hline \multirow[t]{2}{*}{ Прокарбазин } & & $>1,6-6$ ВГН & - & 75 \\
\hline & & $>6 \mathrm{~B} \Gamma \mathrm{H}$ & & На усмотрение лечащего врача \\
\hline Винкристин & $1,5-3,0$ & $>2-3 \mathrm{~B} Г \mathrm{H}$ & Повышена & 50 \\
\hline Винбластин & $>3,1$ & $>3 \mathrm{~B} Г \mathrm{H}$ & - & 0 \\
\hline \multirow[t]{2}{*}{ Винорелбин } & $2,1-3,0$ & - & - & 50 \\
\hline & $>3,0$ & & & 25 \\
\hline \multirow[t]{2}{*}{ Сорафениб } & $<1,5$ ВГН & $\mathrm{ACT}>\mathrm{B} \Gamma \mathrm{H}$ & & 400 мг 2 раза в сутки \\
\hline & 1,5-3 ВГН & $\begin{array}{l}\text { Любой } \\
\text { уровень АСТ }\end{array}$ & & 200 мг 2 раза в сутки \\
\hline $\begin{array}{l}\text { Сорафениб } \\
\text { при альбумине } \\
<2,5 \text { г/дл }\end{array}$ & Любой уровень & $\begin{array}{l}\text { Любой } \\
\text { уровень }\end{array}$ & & 200 мг в сутки \\
\hline Бортезомиб & $>1,5$ ВгН & & & $0,7 \mathrm{Mr} / \mathrm{M}^{2}$ \\
\hline
\end{tabular}

ВГН-верхняя граница нормы.

На сегодняшний день среди препаратов, используемых для коррекции лПП, наибольшей доказательной базой обладает S-аденозилметионин (SAMe, AdoMet) - метаболически плейотропная молекула, которая участвует во множестве биохимических процессов в клетке, выступая в качестве донора метильной группы в реакциях метилирования нуклеиновых кислот, фосфолипидов, гистонов, биогенных аминов и протеинов. Кроме того, S-аденозилметионин является предшественником глутатиона - основного антиоксиданта в гепатоците.

Основываясь на доступном клиническом опыте, назначение S-аденозил-метионина в дозе 800 мг в сутки парентерально в течение 2 недель, с последующим переходом на пероральный приём в дозе 800-1600 мг в сутки показало наибольшую эффективность 
в лечении ЛПП, индуцированном противоопухолевыми препаратами. Общая длительность терапии зависит от динамики биохимических показателей и может составлять от 3 до 6 месяцев. Эффективность терапии S-аденозилметионином необходимо оценивать по степени снижения уровня печёночных аминотрансфераз.

При холестатическом/смешанном варианте поражения печени возможно совместное назначение S-аденозилметионина с препаратами урсодезоксихолевой кислоты (УДХК) в дозе 15-20 мг/кг массы тела в 2-3 приёма до разрешения холестаза.

\section{2. Лечение гепатотоксичности, ассоциированной с применением ингибиторов контрольных точек}

Иммунотерапия раковых заболеваний с использованием селективных моноклональных антител, блокирующих «контрольные точки» иммунного ответа (immune checkpoint inhibitors), находит всё большее применение в терапии раковых заболеваний. Рекомендации по мониторингу и ведению пациентов с лекарственным поражением печени, ассоциированным с терапией ингибиторами контрольных точек, представлены в табл. 6.

Таблица 6. Тактика ведения пациентов с лекарственным поражением печени, вызванным терапией ингибиторами контрольных точек

\begin{tabular}{|c|c|c|}
\hline $\begin{array}{l}\text { Степень } \\
\text { гепатотоксич- } \\
\text { ности }\end{array}$ & $\begin{array}{l}\text { Изменение } \\
\text { лабораторных } \\
\text { показателей }\end{array}$ & Тактика ведения \\
\hline 1 & $\begin{array}{l}\text { АЛТ, АСТ >1-3 ВГН; } \\
\text { Общий билиру- } \\
6 и н>1-1,5 \text { ВГН }\end{array}$ & $\begin{array}{l}\text { • Продолжить терапию } \\
\text { · Б/х анализ крови, оценка функции печени раз в неделю }\end{array}$ \\
\hline 2 & $\begin{array}{l}\text { АЛТ, АСТ > } 3 \leq 5 \text { ВГН; } \\
\text { Общий билиру- } \\
\text { бин >1,5 } \leq 3 \text { ВГН }\end{array}$ & $\begin{array}{l}\text { - Приостановить терапию } \\
\text { - Исключить вирусные гепатиты, аутоиммунные заболевания } \\
\text { печени, билиарную обструкцию, новые метастазы или } \\
\text { тромбоз } \\
\text { - Назначить преднизолон 0,5-1 мг/кг/сут (или метилпреднизо- } \\
\text { лон в эквивалентной дозе) на } 4 \text { недели, с последующим } \\
\text { уменьшением дозировки } \\
\text { - Контроль 6/х показателей дважды в неделю } \\
\text { - При необходимости-проведение биопсии печени } \\
\text { - Возобновить терапию ингибиторами контрольных точек } \\
\text { возможно при снижении дозы преднизолона до } 10 \text { мг/сут } \\
\text { (улучшение 6/х показателей до } 1 \text { степени гепатотоксичности) }\end{array}$ \\
\hline $3-4$ & $\begin{array}{l}\text { АлТ, АСТ > } 5 \text { ВГН; } \\
\text { Общий билиру- } \\
\text { бин > } 3 \text { ВГН }\end{array}$ & 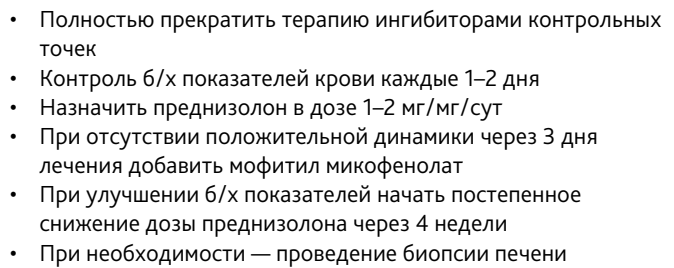 \\
\hline
\end{tabular}

ВГН-верхняя граница нормы 
Нежелательные явления терапии, приводящие к развитию лекарственного поражения печени, обычно протекают по типу бессимптомного повышения уровня печёночных аминотрансфераз, а также в ряде случаев общего билирубина. Обычно отмечаются на 6-14 неделе с начала лечения ингибиторами контрольных точек и в некоторых случаях сопровождаются повышением температуры тела. Частота развития лекарственной гепатотоксичности зависит от дозировки назначаемых препаратов и варьирует от 5 до $30 \%$. 